\title{
DESCRIPTION OF A NEW SPECIES OF LIPARUS FROM WEST AUSTRALIA.
}

\author{
By J. C. Cox, M.D., F.L.S. \\ Buliminus (Liparus) gratwicki, n.sp.
}

(Figs. 1-3.)

Shell cylindrically pyramidal, deeply rimate. The shells before me are a dead chalky white (this may only be a bleached condition of an otherwise coloured shell); whorls seven and a half (of which the uppermost two are nepionic), roundied, slowly increasing in length, and separated by a narrow deeply impressed suture, the last whorl is $17 \mathrm{~mm}$. long and $10 \mathrm{~mm}$. wide; the surface of the whorls is rough, having longitudinal arcuate riblets formed by lines of growth irregularly disposed in larger and smaller groups sharply outlined; these cross each whorl, except the apical, from above downwards and plicate the suture as they end in and commence from it; on the upper whorls, commencing as they do about the middle of the 3rd whorl, these arcuate riblets are only slightly raised, but become harsher as they

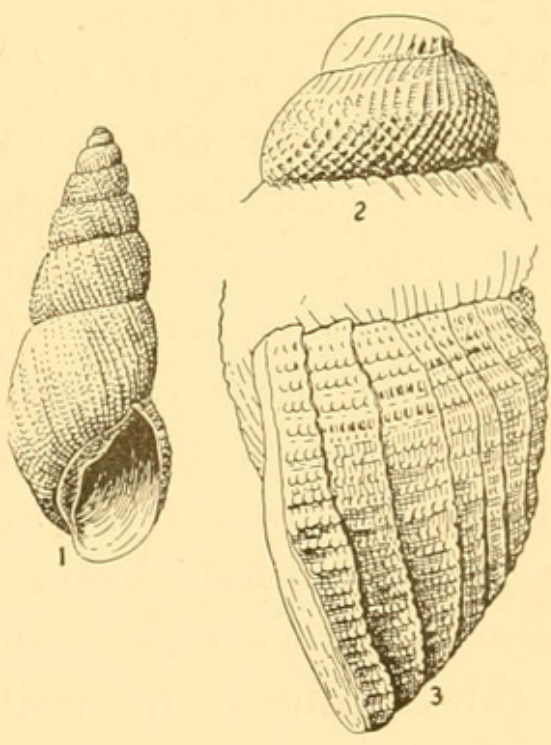
descend. The nepionic whorls are sculptured by a very distinct network of oblique reticulating wrinkles. The longitudinal riblets are cut across at right angles by numerous fine spiral grooves commencing about the 3rd whorl and continuing in a spiral manner till they reach the body whorl; as they pass 
round the lower part of the body whorl their impressed character is not so marked. The longitudinal arcuate riblets being cut across by the spiral grooves, the surface is divided into coarse and fine imbricating subsquamose nodosities, causing the surface to resemble bead-like rows, with finer longitudinal beaded rows in between the coarser ones.

Aperture slightly oblique, pyriform; outer lip simple, neither thickened nor reflected, meeting the body whorl at a sharp angle, then slightly bent and regularly curving to the anterior extremity, where it is aflittle produced and almost effuse. Columella nearly straight, anteriorly everted over the rimate umbilicus; above spreading a thick and sharply defined layer of callus on the body whorl.

Length $30 \mathrm{~mm}$. Width about the middle of the body whorl $10 \mathrm{~mm}$.

Hab. - About 50 miles east of Israelite Bay, Western Australia, two miles from the edge of the cliffs, which are there about 200 feet high; it was found in large numbers. Bulinus Dux is also found abundantly there.

The nearest ally of this species is Liparus Brazieri, Angas, a broader, shorter and much thinner shell. The surface of $L$. gratwicki is correlated with a sharper, harsher sculpture.

The nepionic apex to which I have drawn attention is the same in all other members of Liparus, although, except in the case of L. Spenceri, it has received little attention from authors.

I have placed this species in with Liparus, although so far nothing is known of the anatomy of the animal, but its general characters and habitat suggest that it should be so placed; it has characters, however, as to shape, the formation of its aperture with its thick callused internal surface, that would place it with Placostylus.

The drawing of this species has been generously made for me by Mr. Charles Hedley, Conchologist on the scientific staff of the Australian Museum. 


\section{$2 \mathrm{BHL}$ Biodiversity Heritage Library}

Cox, James Charles. 1899. "Description of a new species of Liparus from west Australia." Proceedings of the Linnean Society of New South Wales 24, 435-436. https://doi.org/10.5962/bhl.part.7676.

View This Item Online: https://www.biodiversitylibrary.org/item/21735

DOI: https://doi.org/10.5962/bhl.part.7676

Permalink: https://www.biodiversitylibrary.org/partpdf/7676

\section{Holding Institution}

MBLWHOI Library

\section{Sponsored by}

MBLWHOI Library

\section{Copyright \& Reuse}

Copyright Status: NOT_IN_COPYRIGHT

This document was created from content at the Biodiversity Heritage Library, the world's largest open access digital library for biodiversity literature and archives. Visit BHL at https://www.biodiversitylibrary.org. 